RESEARCH REPORT

\title{
Social capital and collective efficacy in Hungary: cross sectional associations with middle aged female and male mortality rates
}

\author{
Á Skrabski, M Kopp, I Kawachi
}

J Epidemiol Community Health 2004;58:340-345. doi: 10.1136/jech.2003.010017

See end of article for authors' affiliations

.....................

Correspondence to: Professor I Kawachi, Harvard School of Public Health, 677 Huntington Avenue Boston, MA, USA 02115; ckawach@aol.com

Accepted for publication 4 July 2003
Objectives: Social capital, collective efficacy, and religious involvement have each been linked to population health. This study examined the relations between these measures and male/female mortality rates in Hungary.

Design: Cross sectional, ecological study.

Setting: 150 sub-regions of Hungary.

Participants and methods: 12643 people were interviewed in 2002 (the "Hungarostudy 2002" survey). Social capital was measured by lack of social trust, reciprocity between citizens, and membership in civil organisations. Collective efficacy was measured by survey items from the Project on Human Development in Chicago Neighborhoods. Religious involvement was measured by church attendance.

Main outcome measure: Gender specific all cause mortality rates for the middle aged population (45-64 years) in the 150 sub-regions of Hungary, provided by the Central Statistical Office (CSO).

Results: Social capital, collective efficacy, as well as religious involvement were each significantly associated with middle age mortality. After education, collective efficacy showed the strongest association with mortality in both men and women. Among men, socioeconomic status, collective efficacy, social distrust, competitive attitude, reciprocity, and membership of civic organisations explained $68.0 \%$ of the sub-regional variations in mortality rates. Among women the same variables explained only $29.3 \%$ of the variance in mortality rates. Religious involvement was protective among women.

Conclusion: Collective efficacy and social capital are significant predictors of mortality rates in both men and women across sub-regions of Hungary. Gender differences in the relative importance of social factors may help to explain the differential impact of economic transformation on mortality rates for men and women in Central-Eastern European countries.
O $\mathrm{n}$ the heels of economic and societal transformation in the late 1980s, mortality rates among middle aged (45-64 year) men in Hungary rose to levels higher than in the 1930s. ${ }^{1-3}$ In the 1970s, significant ownership of private property was still uncommon in Hungarian society, with the state employing all citizens, and salaries being determined centrally so that not even persons with high status could accumulate significant wealth. The governing communist party primarily provided privileges to party members, which was expressed as differences in salaries only to a minor degree. Beginning in the 1970s, however, the ruling communist elite began a process of loosening the rules to enable certain influential people to transform public property for private gain. ${ }^{4}$ The ideology of meritocracy and economic competition began to take hold. In many cases the competitive opportunities consisted of seizing public property for personal enrichment.

The theory of relative deprivation, introduced by Runciman, ${ }^{5}$ hypothesises that stress and frustration can arise out of situations in which there is rapid improvement in living standards (for some but not all). As summarised by Coleman ${ }^{6}$ :

\footnotetext{
"As long as there is no visible change in objective conditions, all persons feel that they are "in the same boat". However, when there is rapid improvement in conditions, those of some improve more rapidly than those of others. Those for whom conditions are not improving very rapidly see others, perhaps no more qualified, doing
}

much better than they are. It is from this perspective that they perceive a widening gap, which leads them to feel frustration" (pages 475-6).

Interestingly, not all regions of Hungary experienced changes in mortality at the same rate. We have previously speculated that regional variations in social cohesion and "social capital" partly account for the mortality variations across areas of Hungary. ${ }^{7}$ Social capital is defined as the assets and resources available to individuals through their connections to their communities..$^{8-10}$ Communities richer in stocks of social capital are hypothesised to be better at buffering the stresses and uncertainties associated with economic transformation. ${ }^{11}$

We previously reported cross sectional associations of social capital with mortality rates across the 20 counties of Hungary, based on the Hungarostudy 1995, a national cross sectional survey representing the Hungarian population. ${ }^{7}$ In 1995, 12640 persons were interviewed in their homes. Measures of social capital (trust, perceptions of reciprocity, civic engagement) were significantly associated with mortality rates, with levels of mistrust showing the strongest associations. $^{?}$

The aim of this study was to extend our earlier investigations using new data from the 2002 Hungarostudy, a regionally representative interview survey of the Hungarian population. In contrast with the earlier 1995 Hungarostudy, ${ }^{7}$ the new survey was representative down to the level of 150 sub-regions of the country, enabling us to test the relations 
between social capital and mortality rates at a much smaller level of aggregation than was previously possible. In addition, the 2002 survey included a more detailed battery of scales tapping into the multidimensional concept of social capital, including collective efficacy, ${ }^{12}$ trust, perceived reciprocity, and religiosity. ${ }^{13}$ We also added a new item assessing individual attitudes towards competition.

One of the striking observations about the pattern of mortality in Hungary (indeed throughout the Central European region) is the high male/female mortality gap. In Hungary, the male/female differences in life expectancy is 8.3 years, which is considerably higher than the average difference found in countries of Western Europe, for example 5.8 years in neighbouring Austria, and 4.8 years in Denmark and Great Britain. The educational gradient in mortality is also steeper in Hungarian men (mortality ratio of 1.8 comparing top to bottom) compared with women (1.2). ${ }^{14}$ We therefore sought to examine gender differences in the relations of socioeconomic and psychosocial variables with male/female mortality rates.

\section{METHODS}

The Hungarostudy 2002 is a national cross sectional survey representing the Hungarian population at the level of the 150 sub-regions of Hungary. Altogether, 12643 persons were interviewed in their homes. ${ }^{7}{ }^{15}$

\section{Sampling methods}

A clustered, stratified sampling procedure was implemented. The sample represented $0.16 \%$ of the population above age 18 according to age and sex. The sampling frame was the National Population Register updated by the 2001 national census. Communities with population more than 10000

\section{What is already known about this topic?}

- Social capital-defined as the assets and resources available to individuals through civic participation - is a potential determinant of population health status.

- Indicators of social capital-perceived trust, reciprocity, and membership in civic and religious organisations-correlate with mid-aged (45-64 years) male and female mortality across the 20 counties of Hungary.

\section{What this study adds}

- Indicators of social capital (perceived trust of others, reciprocity, and membership in civic organisations), collective efficacy, religious involvement and competitive attitude are associated with all cause mid-aged (45-64 years) male and female mortality across the 150 sub-regions of Hungary.

- There are gender differences in the relations of competitive attitude and religious involvement with mortality rates. Competitive attitude was a significant predictor of mortality only among men, while religious involvement was a significant protective factor only in women.

- Socioeconomic status (educational attainment and taxable income), social capital, and collective efficacy explained $68.0 \%$ of the sub-regional variance in middle aged male mortality rates.

- Among women, socioeconomic status, social capital, and collective efficacy explained only $29.3 \%$ of the variance in mortality rates. were included in the sample, as well as a random sample of smaller villages. The overall refusal rate was $17.7 \%$, although there were significant differences depending on urban/rural residence. In large cities the refusal rate was higher than in small villages. For each refusal, we selected another person from the same community with similar sampling characteristics defined by age and sex. The replacement sampling procedure was found not to result in significant selection bias.

\section{Dependent and independent variables}

Our outcome variable was male and female all cause mortality rates in the 45-64 year age group, between 19962000, obtained for each sub-region from the Central Statistical Office (CSO). ${ }^{16}$

Following Putnam ${ }^{17}$ and Kawachi, ${ }^{10}$ social capital was assessed by three items inquiring about social trust, perceptions of reciprocity, and membership in civic organisations. ${ }^{7}$ Trust was assessed by aggregating responses to the item that asked whether the respondent agreed that "People are generally dishonest and they want to take advantage of others." (Responses 0-3; totally disagree to totally agree).

Citizens' perceptions of reciprocity were assessed from responses to the item "If I help someone, I can anticipate that they will treat me just as well as I treat them." (Responses $0-3$; totally disagree to totally agree).

Membership in civic organisations was measured by yes/no responses to a question about belonging to civic groups. Civic organisations were defined as non-profit, voluntary organisations, societies, self help groups, and clubs. Political parties, unions, and churches were not included.

The survey included the collective efficacy scale from the 1995 Community Survey of the Project on Human Development in Chicago Neighborhoods, a seminal study of social capital in the USA. ${ }^{12}$ Collective efficacy is defined as the collective belief in undertaking coordinated action. ${ }^{18}$ The questionnaire assesses the differential ability of neighbourhoods to realise the common values of residents, which is referred to as "social cohesion". The other component assesses "informal social control", which concerns the belief in the likelihood that neighbours will intervene in risky situations. The collective efficacy scale is derived by summing the responses to the 10 items that make up the scale (see appendix).

Individual attitudes towards competition was assessed by the question "If I hear about the success of a friend of mine, I feel frustrated" (Responses: 0-3, totally disagree to totally agree). This question is part of the shortened Hostility Questionnaire. $^{15}$

Religious involvement was measured by the question:"Are you religious? If yes, what is the form of your worship?" (Responses 0-4; "I am not religious" to "I worship regularly in my church").

We calculated the population weighted, standardised values of the above variables for each of the 150 Hungarian sub-regions, separately for men and women.

\section{Socioeconomic and behavioural covariates}

We controlled for the following socioeconomic variables: taxable income per capita and average years of educational attainment at the sub-regional level, obtained from the CSO. We also obtained cigarette smoking per day and spirit consumption per occasion for each sub-region from the Hungarostudy 2002 survey. SPSS version 7.5 was used for multivariate analyses; stepwise regression analyses were used to explain mortality differences among sub-regions and one way analysis of variance for comparing means according to gender. ${ }^{19}$ 


\section{RESULTS}

The Cronbach $\alpha$ for the 10 item collective efficacy scale was 0.83 , indicating a high level of internal consistency reliability. Table 1 shows the characteristics of the study population.

Table 2 shows the correlations among social capital variables before and after controlling for education and income.

Higher income and educational attainment were significantly negatively correlated with social distrust $(r=-196$, and -0.172 , respectively), competitive attitude $(r=-408$ and -0.420$)$, and positively correlated with membership in civic organisations $(r=0.141$, and 0.159). However, higher income and educational attainment were also negatively correlated with collective efficacy $(r=-0.667$ and -0.707 , respectively), with reciprocity $(r=-554$ and -0.552$)$, and with religious involvement $(r=-0.224$ and -0.262$)$. These patterns suggest that collective efficacy, reciprocity, and religious involvement are all significantly higher in less economically developed sub-regions of Hungary.

Because of the opposing influences of socioeconomic variables on different social capital indicators, we adjusted the correlations by education and income (table 2 ). The social capital variables (trust, reciprocity, and membership in civic organisations) were moderately, and significantly, correlated with each other. Competitive attitude was significantly inversely correlated with indicators of social capital. Religious involvement was positively correlated with perceptions of reciprocity, collective efficacy, and membership of civic organisations. However, it was not significantly correlated with mistrust, and it was positively correlated with competitive attitude.

Relations between social capital and male and female middle aged mortality rates

After controlling for socioeconomic variables as well as stress related coping behaviours (cigarette smoking and spirit consumption), stepwise multivariable regression analyses indicated that the social capital variables (social distrust, reciprocity, and membership in civic organisations), as well as collective efficacy, religious involvement, and competitive attitude were each significantly associated with mortality rates (tables 3 and 4). Among men, the above variables explained $68.0 \%$ of the mortality variance across sub-regions (table 3). Years of education alone explained $61.8 \%$ of the variance in male mortality rates, but the next significant predictor in stepwise regression was collective efficacy. Interestingly, religious involvement among men was positively correlated with mortality. Among women, the variables in the multivariable model explained only $29.3 \%$ of the mortality differences across sub-regions (table 4). After taxable income, collective efficacy, daily cigarette smoking, and religious involvement were the most important predictors of middle aged female mortality. Interestingly, among women, competitive attitude was not significantly related to mortality, although the average values of competitive attitude were not significantly different between men and women $(\mathrm{p}=0.405)($ table 1$)$.

Cigarette smoking, when it was entered alone into the regression models explained $10.5 \%$ of variance in male and $10.0 \%$ in the female mortality differences.

\section{DISCUSSION}

This study extends the previous findings of an association between social capital and area level variations in mortality rates in Hungary. ${ }^{7}$ The 1995 Hungarostudy established an association between social capital and mortality rates across the 20 counties of Hungary. ${ }^{7}$ This study, based on the recently released Hungarostudy 2002, replicates and extends the association down to the 150 sub-regions of the country.

Our findings are limited by the cross sectional and ecological design of our study. Causal interpretations would be strengthened by multilevel studies (teasing out the truly

Table 1 Characteristics of the study population in the 150 sub-regions of Hungary

\begin{tabular}{|c|c|c|c|c|c|c|c|}
\hline & & Mean & Standard error & Minimum & Maximum & $F$ statistic & p Value* \\
\hline \multirow{3}{*}{$\begin{array}{l}\text { Death rate per } 100000 \\
\text { (ages 45-64), 1996- } \\
2000\end{array}$} & male & 105.70 & 1.12 & 78.50 & 138.71 & 3022.86 & 0.000 \\
\hline & female & 40.23 & 0.40 & 29.18 & 53.52 & & \\
\hline & Total & 72.96 & 1.98 & 29.18 & 138.71 & & \\
\hline & male & 10.52 & 0.06 & 8.60 & 12.68 & 3.71 & 0.055 \\
\hline & female & 10.33 & 0.08 & 8.60 & 14.21 & & \\
\hline & Total & 10.42 & 0.05 & 8.60 & 14.21 & & \\
\hline \multirow[t]{3}{*}{ Collective efficacy } & male & 26.09 & 0.19 & 19.95 & 33.60 & 7.25 & 0.007 \\
\hline & female & 26.80 & 0.19 & 20.30 & 35.11 & & \\
\hline & Total & 26.45 & 0.13 & 19.95 & 35.11 & & \\
\hline \multirow[t]{3}{*}{ Perceived reciprocity } & male & 1.90 & 0.02 & 1.11 & 2.83 & 8.55 & 0.004 \\
\hline & female & 1.81 & 0.02 & 1.19 & 2.69 & & \\
\hline & Total & 1.86 & 0.02 & 1.11 & 2.83 & & \\
\hline \multirow{3}{*}{ Social mistrust } & male & 0.98 & 0.02 & 0.25 & 1.83 & 4.55 & 0.034 \\
\hline & female & 0.91 & 0.02 & 0.18 & 2.20 & & \\
\hline & Total & 0.94 & 0.02 & 0.18 & 2.20 & & \\
\hline \multirow[t]{3}{*}{ Competitive attitude } & male & 0.34 & 0.01 & 0.06 & 1.00 & 0.69 & 0.405 \\
\hline & female & 0.32 & 0.01 & 0.06 & 0.83 & & \\
\hline & Total & 0.33 & 0.01 & 0.06 & 1.00 & & \\
\hline Membership in civic & male & 0.15 & 0.01 & 0.00 & 0.57 & 32.67 & 0.000 \\
\hline \multirow[t]{2}{*}{ organisation } & female & 0.09 & 0.01 & 0.00 & 0.78 & & \\
\hline & Total & 0.12 & 0.01 & 0.00 & 0.78 & & \\
\hline \multirow{3}{*}{ Religious involvement } & male & 1.59 & 0.04 & 0.68 & 3.00 & 75.02 & 0.000 \\
\hline & female & 2.09 & 0.04 & 0.69 & 3.32 & & \\
\hline & Total & 1.84 & 0.03 & 0.68 & 3.32 & & \\
\hline \multirow[t]{3}{*}{ Cigarettes per day } & male & 6.48 & 0.18 & 1.20 & 14.05 & 248.70 & 0.000 \\
\hline & female & 3.01 & 0.12 & 0.11 & 8.85 & & \\
\hline & Total & 4.74 & 0.14 & 1.02 & 14.05 & & \\
\hline Spirit consumption & male & 0.51 & 0.02 & 0.06 & 1.67 & 121.01 & 0.000 \\
\hline \multirow[t]{2}{*}{$(0.5 \mathrm{dl})$} & female & 0.21 & 0.01 & 0.06 & 1.20 & & \\
\hline & Total & 0.37 & 0.02 & 0.06 & 1.67 & & \\
\hline $\begin{array}{l}\text { Taxable income } \\
\text { thousand HUF }\end{array}$ & Total & 344 & 0.1 & 154 & 546 & & \\
\hline
\end{tabular}


Table 2 Correlations among social capital, competitive attitude, collective efficacy, and religious involvement variables $†$

\begin{tabular}{|c|c|c|c|c|c|}
\hline & $\begin{array}{l}\text { Collective } \\
\text { efficacy }\end{array}$ & Reciprocity & Social mistrust & $\begin{array}{l}\text { Competitive } \\
\text { attitude }\end{array}$ & $\begin{array}{l}\text { Membership in } \\
\text { civic organisation }\end{array}$ \\
\hline Reciprocity & $\begin{array}{l}0.235^{* *} \\
\left(0.529^{* *}\right)\end{array}$ & & & & \\
\hline Social mistrust & $\begin{array}{l}-0.141^{\star *} \\
\left(0.025^{* \star}\right)\end{array}$ & $\begin{array}{l}0.148^{* *} \\
\left(0.226^{* *}\right)\end{array}$ & & & \\
\hline $\begin{array}{l}\text { Competitive } \\
\text { attitude }\end{array}$ & $\begin{array}{l}-0.204^{\star *} \\
\left(0.166^{* \star}\right)\end{array}$ & $\begin{array}{l}-0.046^{* *} \\
\left(0.202^{* *}\right)\end{array}$ & $0.270^{* *}\left(0.317^{* *}\right)$ & & \\
\hline $\begin{array}{l}\text { Membership in } \\
\text { civic } \\
\text { organisation }\end{array}$ & $\begin{array}{l}0.158^{\star *} \\
(-0.002)\end{array}$ & $\begin{array}{l}0.163^{* *} \\
\left(0.048^{* *}\right)\end{array}$ & $0.141^{* *}\left(0.112^{* *}\right)$ & $\begin{array}{l}-0.062^{\star *} \\
\left(-0.121^{* \star}\right)\end{array}$ & \\
\hline $\begin{array}{l}\text { Religious } \\
\text { involvement }\end{array}$ & $\begin{array}{l}0.132^{* \star} \\
\left(0.274^{\star *}\right)\end{array}$ & $\begin{array}{l}0.020^{*} \\
\left(0.154^{\star \star}\right)\end{array}$ & $0.003\left(0.042^{* *}\right)$ & $0.088^{* *}\left(0.184^{* *}\right)$ & $0.091^{* *}\left(0.043^{* *}\right)$ \\
\hline
\end{tabular}

†Pearson correlations unadjusted for education or income; partial correlation coefficients (adjusted for education and income in parentheses). ${ }^{*} \mathrm{p}<0.05$ (two tailed); ${ }^{* *} \mathrm{p}<0.001$ (two tailed).

contextual effects of sub-regional characteristics from compositional effects), as well as by longitudinal follow up (assessing change in mortality against change in social capital). In addition, some of our measures of social capital are proxy measures at best, and they do not capture the complexity of the underlying construct. ${ }^{20}$

As in our earlier study, ${ }^{7}$ noteworthy gender differences were found in the correlates of regional mortality patterns. Among men, educational attainment was the strongest determinant of mortality rates, alone accounting for $61.8 \%$ of the variance across sub-regions. Beyond educational attainment, however the social cohesion variables (collective efficacy, mistrust, membership of civic organisations, and reciprocity) each made significant contributions to mortality rates.

High risk health behaviours such as cigarette smoking and spirit consumption-although frequently invoked to explain the Central and Eastern European mortality paradox-added only $0.4 \%$ to the explained variance in the stepwise regression models of male mortality rates (although in an unadjusted model, cigarette smoking explained $10 \%$ of mortality differences). These risk behaviours seem to be epi-phenomena, reflecting deeper social forces.

The theory of relative deprivation suggests that invidious social comparisons triggered during periods of rapid economic change may lead to stress and frustration, especially among those who are left behind on the socioeconomic hierarchy. ${ }^{6}$ Although the strong inverse associations between competitive attitudes and educational attainment $(-0.42)$ and income $(-0.41)$ are consistent with the theory of relative deprivation, caution is warranted in interpreting such findings because our study was ecological, and hence we cannot draw individual level inferences.

Our findings also provide clues that community cohesion may dampen competitive attitudes between citizens, as well as buffer the harmful health consequences of competition. Here also, caution is warranted in drawing causal inferences, given the cross sectional nature of our study. To our knowledge, ours is the first study to report an association between community competitive attitude and male mortality rates. Harbouring competitive attitudes may have adverse health consequences at both the individual level and at the community level. Whether competitive attitudes in the community acts as a deleterious contextual influence on health outcomes remains to be determined in multilevel analyses.

Among women, in contrast with men, taxable income was the most significant determinant of sub-regional mortality rates, accounting for $15 \%$ of the explained variance. Overall, the variables in our multivariable models accounted for a

\begin{tabular}{|c|c|c|c|c|c|}
\hline & $\beta$ & SE & $t$ Test & p Value & Adjusted $r^{2}$ \\
\hline \multicolumn{6}{|l|}{ Model } \\
\hline (Constant) & 187.1 & 2.48 & 75.4 & 0.000 & \\
\hline Years of education & -7.76 & 0.24 & -32.4 & 0.000 & 0.618 \\
\hline Collective efficacy* & -1.13 & 0.05 & -22.1 & 0.000 & 0.641 \\
\hline Taxable income & $-4.63 \mathrm{E}-05$ & 0.006 & $\begin{array}{r}-25.1 \\
15.3\end{array}$ & $\begin{array}{l}0.000 \\
0.000\end{array}$ & 0.660 \\
\hline Social mistrust† & 7.25 & 0.47 & \multirow{2}{*}{11.8} & \multirow{2}{*}{0.000} & 0.671 \\
\hline Cigarettes per day & 0.89 & 0.08 & & & 0.674 \\
\hline Religious involvement & 2.15 & 0.196 & 11.0 & 0.000 & 0.677 \\
\hline & & & \multirow[t]{2}{*}{7.8} & \multirow{2}{*}{0.000} & \\
\hline Competitive antitude $\ddagger$ & 6.10 & 0.78 & & & 0.679 \\
\hline Membership in civic organisations & -7.46 & 1.61 & -4.6 & 0.000 & 0.679 \\
\hline Reciprocity§ & -1.29 & 0.43 & -3.0 & 0.002 & 0.680 \\
\hline Spirit consumption & 1.70 & 0.57 & 2.9 & 0.003 & 0.680 \\
\hline
\end{tabular}

*Measured by the sum of 10 items of Chicago Community Survey Questionnaire; †measured by the average responding, "People are generally dishonest and they want to take advantage of others" (0-3); ¥measured by the average responding, "When I hear of the success of a friend of mine, I feel frustrated" (0-3); §measured by the average responding, "If I help someone, I can anticipate that they will treat me just as well as I treat them" (0-3). 
Table 4 Multivariable linear regression results for middle aged (45-64 years old) female mortality (weighted by the number of interviewed women in the sub-regions) ( $n=6579$ )

\begin{tabular}{|c|c|c|c|c|c|}
\hline & $\beta$ & SE & $t$ Test & p Value & Adjusted $r^{2}$ \\
\hline $\begin{array}{l}\text { Model } \\
\text { (Constant) } \\
\text { Taxable income } \\
\text { Collective efficacy* } \\
\text { Cigarettes per day } \\
\text { Religious involvement } \\
\text { Years in education } \\
\text { Spirit consumption } \\
\text { Social distrust† } \\
\text { Membership in civic organisations } \\
\text { Reciprocity } ¥ \\
\text { Excluded variable: Competitive attitude§ }\end{array}$ & $\begin{array}{l}70.88 \\
-1.03 \mathrm{E}-05 \\
0.60 \\
0.57 \\
-1.67 \\
-1.54 \\
-2.47 \\
2.26 \\
-5.24 \\
-0.92\end{array}$ & $\begin{array}{l}1.08 \\
0.01 \\
0.02 \\
0.03 \\
0.09 \\
0.11 \\
0.26 \\
0.21 \\
0.72 \\
0.19\end{array}$ & $\begin{array}{r}65.8 \\
-12.5 \\
-26.5 \\
16.7 \\
-19.1 \\
-14.5 \\
-9.7 \\
10.9 \\
-7.3 \\
-4.8\end{array}$ & $\begin{array}{l}0.000 \\
0.000 \\
0.000 \\
0.000 \\
0.000 \\
0.000 \\
0.000 \\
0.000 \\
0.000 \\
0.000\end{array}$ & $\begin{array}{l}0.153 \\
0.215 \\
0.249 \\
0.263 \\
0.277 \\
0.283 \\
0.288 \\
0.291 \\
0.293\end{array}$ \\
\hline
\end{tabular}

much smaller proportion of the variance in female mortality rates $(29 \%)$. In contrast with men, competitive attitude was not a predictor of mortality rates in women, while religious involvement was significantly inversely correlated. The apparent "immunity" of women from the effects of competitive attitudes, combined with the stronger beneficial

\section{Key points}

- Indicators of social capital (perceived trust of others, reciprocity, and membership in civic organisations), collective efficacy, religious involvement, and competitive attitude are associated with mid-aged (45-64 years) male and female mortality rates across the 150 sub-regions of Hungary.

- There are gender differences in the relations of competitive attitude and religious involvement with mortality rates. Competitive attitude was a significant predictor of mortality only among men, while religious involvement was a significant protective factor only in women.

- Socioeconomic status (educational attainment and taxable income), social capital, and collective efficacy explained $67.6 \%$ of the sub-regional variance in middle aged male mortality rates, while cigarette smoking and spirit consumption added only $0.4 \%$ of explained variance.

- Among women, socioeconomic status, social capital and collective efficacy explained only $27.3 \%$ of the variance in mortality rates, while cigarette smoking and spirit consumption added a further $2.0 \%$.

\section{Policy implications}

Public health efforts to tackle the Central-Eastern European mortality paradox must target not just high risk behaviours (such as the high prevalence of cigarette smoking and alcohol consumption), but also fundamental social determinants of mortality, including aspects of social cohesion, and relative deprivation accompanying rapid economic transformation. effect of collective efficacy for women, may partly account for the wide gender gap in mortality rates observed in Hungary.

Gender differences in responses to stress have been noted by others. ${ }^{21}$ As a generalisation, men tend to respond to stress by displaying more hostility towards others, by withdrawing socially, or by engaging in damaging coping behaviours such as substance misuse. By contrast, women tend to cope with stressful situations by actively seeking social support, and engaging in a variety of "tending and befriending" behaviours. ${ }^{21}$ In the absence of individual level data, such an explanation remains speculative. None the less, the gender differences observed in our data provide some tantalising clues to the mystery of the gender gap in mortality observed in Hungary (and indeed much of Central and Eastern Europe) after economic and societal transformation.

\section{ACKNOWLEDGEMENTS}

The authors would like to thank to the other members of the "Hungarostudy 2002" team, to the network of district nurses for the home interviews, for Professor András Klinger for the sampling procedure.

\section{Authors' affiliations}

Á Skrabski, Apor Vilmos College, Zsámbék, Hungary

M Kopp, Institute of Behavioural Sciences, Semmelweis University of Medicine, Budapest, Hungary

I Kawachi, Center for Society and Health, Harvard School of Public Health, Boston, USA

Funding: this study was supported by the NKFP-01/002/2001, by the UNDP HUN/00/002/A/01/99, and the OTKA T-32974 (2000) and TS- 040889 (2002) projects.

Conflicts of interest: none declared.

\section{APPENDIX}

\section{COLLECTIVE EFFICACY SCALE (FROM THE 1995 COMMUNITY SURVEY OF THE PROJECT ON HUMAN DEVELOPMENT IN CHICAGO NEIGHBOURHOODS ${ }^{12}$ )}

- 0 strongly disagree

- 1 disagree

- 2 neither agree nor disagree

- 3 agree

- 4 strongly agree

If there is a problem around here, the neighbours get together to deal with it.

This is a close knit neighbourhood. 
When you get right down to it, no one in this neighbourhood cares much about what happens to me.

There are adults in this neighbourhood that children can look up to.

People around here are willing to help their neighbours.

People in this neighbourhood generally don't get along with each other.

People in this neighbourhood can be trusted.

Adults in this neighbourhood know who the local children are.

Parents in this neighbourhood generally know each other.

If a group of neighbourhood children were skipping school and hanging out on a street corner, the neighbours would do something about it.

\section{REFERENCES}

1 Central Statistical Office. Demographic yearbook of Hungary. Budapest: CSO, 2001.

2 Bobak M, Marmot M. East-West mortality divide: proposed research agenda. BMJ 1996;312:421-5.

3 Marmot M, Wilkinson RG. The social determinants of health. Oxford: Oxford University Press, 1999.

4 Spéder ZS. Hungary in flux, society, politics and transformation. Kramer: Hamburg, 1999.

5 Runciman WG. Relative deprivation and social justice. Berkeley: University of California Press, 1966.

6 Coleman JS. Foundations of social theory. Cambridge, MA: Harvard University Press, 1990.
7 Skrabski Á, Kopp MS, Kawachi I. Social capital in a changing society: cross sectional associations with middle aged female and male mortality. J Epidemiol Community Health 2003;57:114-19.

8 Kawachi I, Berkman LF. Social cohesion, social capital, and health. In: Berkman LF, Kawachi I, eds. Social epidemiology. New York: Oxford University, 2000:174-90.

9 Kawachi I, Kennedy BP. Health and social cohesion: why care about income inequality? BMJ 1997:314:1037-40.

10 Kawachi I, Kennedy BP, Lochner K, et al. Social capital, income inequality, and mortality. Am J Public Health 1997;87:1491-8.

11 Kennedy BP, Kawachi I, Brainerd E. The role of social capital in the Russian mortality crisis. World Development 1998;26:2029-43.

12 Sampson RJ, Raudenbush SW, Earls F. Neighbourhoods and violent crime: a multilevel study of collective efficacy. Science 1997;227:918-24.

13 Hyyppa MT, Maki J. Social participation and health in a community rich in stock of social capital. Health Education Research (in press).

14 Mackenbach JP, Kunst A, Groenhof F, et al. Socioeconomic inequalities in mortality among women and among men: an international study. Am J Public Health 1999;89:1800-8.

15 Kopp MS, Skrabski Á, Szedmák S. Psychological risk factors, inequality and self-rated morbidity in a changing society. Soc Sci Med 2000:51:1350-61.

16 Central Statistical Office. Data Base for Sub-regions of Hungary. Budapest: CSO, 2001.

17 Putnam RD. Making democracy work. Princeton NJ: Princeton University Press, 1993.

18 Sampson RJ. Neighborhood-level context and health: lessons from sociology. In: Kawachi I, Berkman LF, eds. Neighborhoods and health. New York: Oxford University Press, 2003:132-46.

19 SPSS. SPSS manual. The SPSS Base 7.5 for Windows users guide. Chicago, IL: SPSS, 1997.

20 Baum FE, Ziersch AM. Glossary: social capital. J Epidemiol Community Health 2003;57:320-3.

21 Taylor SE. The tending instinct. New York: Tmes Books, 2002. 